\title{
New interesting records of three cavernicolous millipede species from the Crimean Peninsula
}

\section{Новые интересные находки трех пешерных видов диплопод с Крымского полуострова}

\author{
I.S. Turbanov ${ }^{1,2}$, S.I. Golovatch ${ }^{3}$, D. VandenSpiegel ${ }^{4}$ \\ И.С. Турбанов ${ }^{1,2}$, С.И. Головач ${ }^{3}$, А. ВанденШпигель ${ }^{4}$
}

\footnotetext{
${ }^{1}$ The Papanin Institute of the Biology of Inland Waters, Russian Academy of Sciences, Borok, Yaroslavl Region 152742, Russia. E-mail: turba13@mail.ru

${ }^{1}$ Институт биологии внутренних вод имени И.Д. Папанина РАН, Ярославская обл., Борок 152742, Россия

${ }^{2}$ Cherepovets State University, Lunacharskogo pr. 5, Cherepovets, Vologda Region, 162600, Russia.

2 Череповецкий государственный университет, проспект Луначарского, 5, Череповец, Вологодская область, 162600, Россия.

${ }^{3}$ Institute for Problems of Ecology and Evolution, Russian Academy of Sciences, Leninsky prospekt 33, Moscow 119071, Russia. E-mail: sgolovatch@yandex.ru

${ }^{3}$ Институт проблем экологии и эволюции РАН, Ленинский проспект, 33, Москва 119071, Россия.

${ }^{4}$ Musée Royal de l’Afrique Centrale, B-3480 Tervuren, Belgique. E-mail: didier.van.den.spiegel@africamuseum.be
}

KEY WORDS: taxonomy, Caucasodesmus, Syrioiulus, Amblyiulus, new records, cave, Crimea. Крым.

КЛЮЧЕВЫЕ СЛОВА: таксономия, Caucasodesmus, Syrioiulus, Amblyiulus, новые находки, пещера,

ABSTRACT. New records and illustrations are provided for three diplopod species from Crimean caves: Caucasodesmus svetlanae Golovatch et VandenSpiegel, 2015, C. tauricus Golovatch, 2011 and Syrioiulus kovali (Golovatch, 2008), comb.n. ex Amblyiulus Silvestri, 1896. The refined distributions of all five endemic, presumed troglobitic, Crimean millipede species are mapped. The patterns revealed are rooted in and accounted for by the geological history, as well as the karst geomorphological and biospeleological regionalization of the Crimean karst.

How to cite this article: Turbanov I.S., Golovatch S.I., VandenSpiegel D. 2018. New interesting records of three cavernicolous millipede species from the Crimean Peninsula // Arthropoda Selecta. Vol.27. No.3. P.201-209. doi: 10.15298/arthsel. 27.3.02

РЕЗЮМЕ. Даны новые находки и иллюстрации для трех видов диплопод из крымских пещер: Caucasodesmus svetlanae Golovatch et VandenSpiegel, 2015, C. tauricus Golovatch, 2011 и Syrioiulus kovali (Golovatch, 2008), comb.n. ex Amblyiulus Silvestri, 1896. Представлена карта с уточненным распространением всех пяти ныне известных, предположительно троглобионтных видов двупарноногих многоножек Крыма. Наблюдаемые распределения коренятся в геологической истории, а также в карстолого-геоморфологическом и биоспелеологическом районировании крымского карста.
The latest review of the millipede fauna of Crimea, a prominent peninsula in the Black Sea, listed 18 species from 12 genera, eight families and six orders, including five presumably troglobitic species [Golovatch et al., 2017]. The present contribution provides new records and illustrations for three of the cavernicoles, as well as a refined map showing the current distributions of all five Crimean presumed diplopod troglobites. Some geological and biogeographical issues are also discussed to explain the patterns revealed. In addition, one of the species, Amblyiulus kovali Golovatch, 2008, is newly transferred to the genus Syrioiulus Verhoeff, 1914, comb.n., following the recently proposed refined diagnoses of both Amblyiulus Silvestri, 1896 and Syrioiulus [Golovatch, 2018].

\section{Material and methods}

Material serving as the basis for the present contribution was collected by the first author in several caves located in different karsts in the Crimean Peninsula. All material is donated to the Zoological Museum, State University of Moscow (ZMUM), Russia. The samples are stored in 70-75\% ethanol. Specimens for scanning electron microscopy (SEM) were air-dried, mounted on aluminium stubs, coated with gold and studied using a JEOL JSM-6480LV scanning electron microscope, all performed at Tervuren, Belgium. Pictures of the live specimens were made with an Olympus TG-5 digital camera. 

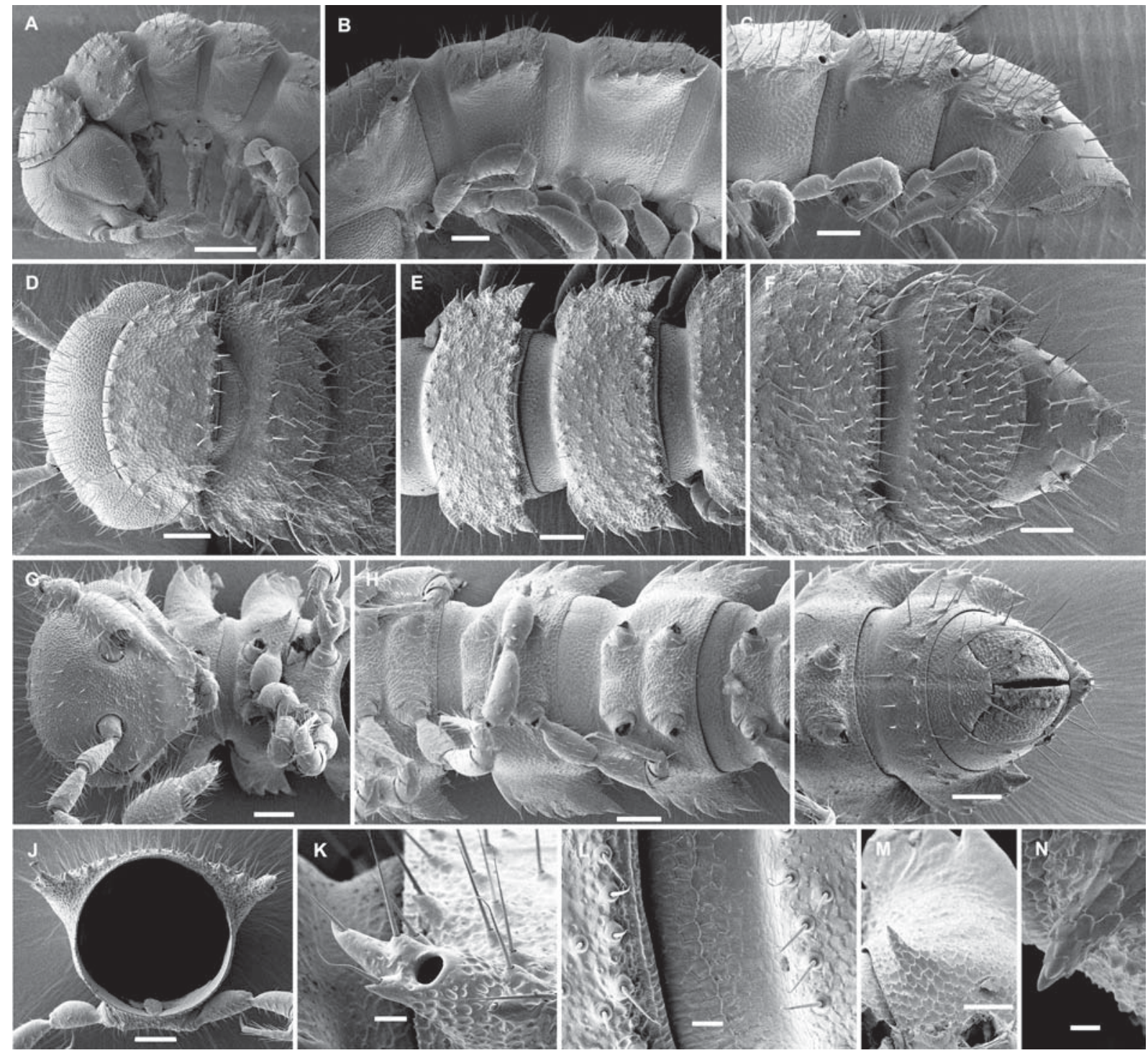

Fig. 1. SEM micrographs to show structural details of Caucasodesmus svetlanae Golovatch et VandenSpiegel, 2015, $\sigma^{7}$ from the Skelskaya Cave: A, D, G - anterior part of body, lateral, dorsal and ventral views, respectively; B, E, H - midbody segments, lateral, dorsal and ventral views, respectively; C, F, I - posterior part of body, lateral, dorsal and ventral views, respectively; J - cross-section of a midbody segment, caudal view; $\mathrm{K}$ - midbody poriferous paratergum, lateral view; $\mathrm{L}$ - texture of tegument, dorsal view; $\mathrm{M}, \mathrm{N}$ pleurosternal spines, ventral and lateral views, respectively. Scale bars: $0.2 \mathrm{~mm}(\mathrm{~A}), 0.1 \mathrm{~mm}(\mathrm{~B}-\mathrm{J}), 0.05 \mathrm{~mm}(\mathrm{~K}), 0.02 \mathrm{~mm}(\mathrm{~L}, \mathrm{M}), 0.01$ $\mathrm{mm}(\mathrm{N})$.

Рис. 1. SEM-микрографии, показывающие структурные детали строения Caucasodesmus svetlanae Golovatch et VandenSpiegel, 2015, о7 из Скельской пещеры: A, D, G - передняя часть тела, соответственно сбоку, сверху и снизу; В, E, Н — среднетуловищные сегменты, соответственно сбоку, сверху и снизу; С, F, I - задняя часть тела, соответственно сбоку, сверху и снизу; J поперечный разрез через среднетуловищный сегмент, сзади; K - среднетуловищный несущий пору паратергит, сбоку; L текстура покровов, сверху; M, N - плевростернальные шипы, соответственно снизу и сбоку. Масштаб: 0,2 мм (A), 0,1 мм (B-J), 0,05 мм (K), 0,02 мм (L, M), 0,01 мм (N).

\section{Taxonomic part}

Caucasodesmus svetlanae Golovatch et VandenSpiegel, 2015

Figs 1, 2.

Caucasodesmus svetlanae Golovatch et VandenSpiegel, 2015: 1 (original description).
Caucasodesmus svetlanae - Turbanov et al., 2016: 1292 (listing); Golovatch et al., 2017: 106 (listing); Turbanov, 2018b: 265 (new records, notes on ecology and conservation).

MATERIAL. 2 오, Crimea, Ai-Petri Karst Massif, Karadag Forest area, Kristalnaya (= Imeni Maksimovicha) Cave, 3.V.2015; $1 \mathrm{O}^{2}$, Ai-Petri Karst Massif, Baydarskaya Valley, near Rodnikovskoe, Skelskaya Cave, 25.IV.2017, all leg. I.S. Turbanov.

REMARKS. The above material repeats the earlier records of this species from the Kristalnaya (= Imeni Maksimovicha) and Skelskaya caves [Turbanov, 2018b], both of 

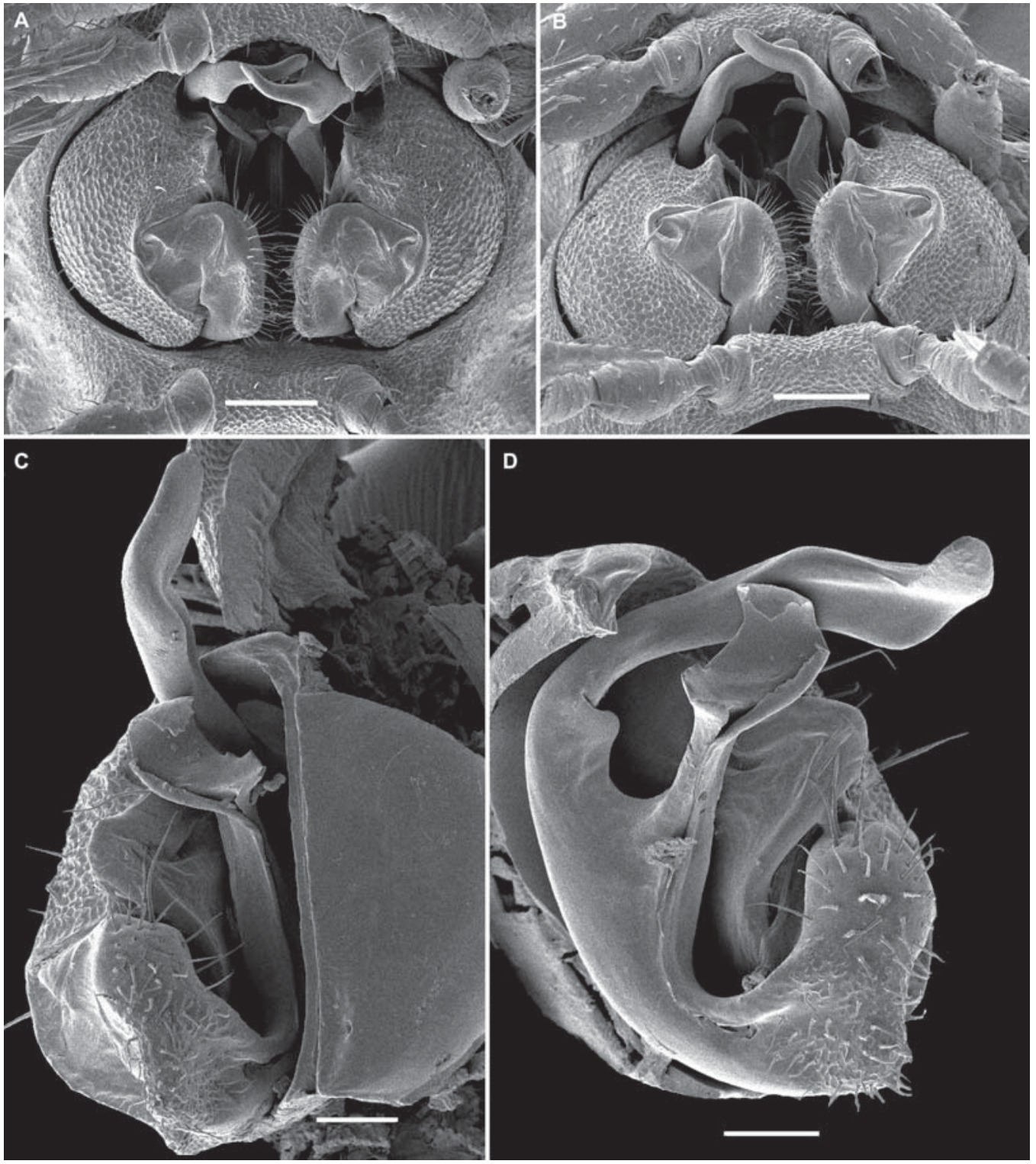

Fig. 2. SEM micrographs to show structural details of the gonopods of Caucasodesmus svetlanae Golovatch et VandenSpiegel, 2015, $\mathrm{O}^{7}$ from the Skelskaya Cave: A, B — both gonopods in situ, ventral and ventrocaudal views, respectively; C, D — left gonopod, ventral and mesal views, respectively. Scale bars: $0.1 \mathrm{~mm}(\mathrm{~A}, \mathrm{~B}), 0.05 \mathrm{~mm}(\mathrm{C}, \mathrm{D})$.

Рис. 2. SEM-микрографии, показывающие структурные детали строения гоноподов Caucasodesmus svetlanae Golovatch et VandenSpiegel, 2015, О7 из Скельской пещеры: А, В - оба гонопода на месте, соответственно снизу и одновременно снизу и сзади; C, D - левый гонопод, соответственно снизу и изнутри. Масштаб: 0,1 мм (A, B), 0,05 мм (C, D).

which lie very close to the Kuznetsova (= Koryta) Cave, the locus typicus [Golovatch, VandenSpiegel, 2015]. All samples of C. svetlanae stem from caves (Map) lying within the karst erosion blocks of the Karadag Forest area's valley in the western part of the Ai-Petri Karst Massif (= Ai-Petri Yaila) [Vakhrushev, 2009] which are located in pure, massif, upper Tithonian to lower Valangian limestones of Jurassic age [Lysenko, 1964].

The new material fully matches the types in morphological details, including the gonopodal conformation (Figs 1, 2). Superficially, all Crimean Caucasodesmus species look very much alike (Fig. 3), the differences lying only in gonopodal structure.

\section{Caucasodesmus tauricus Golovatch, 2011}

Figs 4, 5. tion).

Caucasodesmus tauricus Golovatch, 2011: 2 (original descrip-

Caucasodesmus tauricus - Golovatch, VandenSpiegel, 2015: 6 (key); Turbanov, 2015: 69 (new records, notes on ecology and conservation); Turbanov et al., 2016: 1292 (record, listing); Golovatch et al., 2017: 106, 110 (listing).

MATERIAL. $4 \sigma^{7} \sigma^{7}, 1$, Crimea, Bakhchisaray Distr., NW spurs of Ai-Petri Karst Massif, Chaynyi Domik area, Beryu-Teshik (= Partizanskaya) Cave, 17.VII.2017, leg. I.S. Turbanov.

REMARKS. The above material repeats the earlier record of this species from the Beryu-Teshik Cave [Turbanov, 2015; 


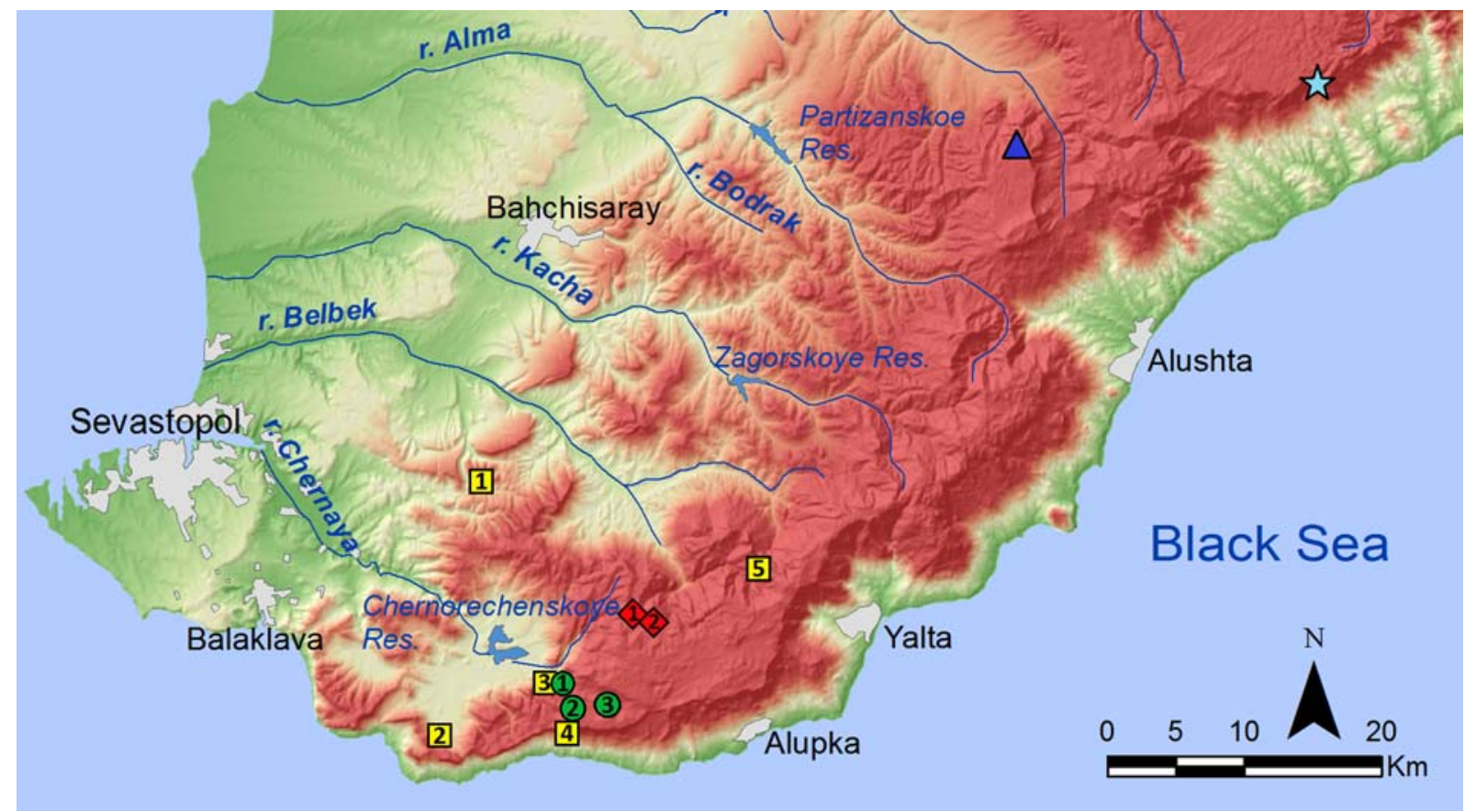

Map. Distributions of all five known endemic troglobitic millipedes in the Crimean Peninsula: The species Syrioiulus kovali (yellow square): 1 - Mangupskaya I (= MK-1) Cave, 2 - Mamut- Tshokrak Cave, 3 - Skelskaya Cave, 4 - Druzhba Cave, 5 - Avantyura Cave. The species Caucasodesmus svetlanae (green circle): 1 - Skelskaya Cave, 2 - Kuznetsova (= Koryta) Cave, 3 - Kristalnaya (= Imeni Maksimovicha) Cave. The species C. tauricus (red diamond): 1 - Beryu-Teshik (= Partizanskaya) Cave, 2 - Villyaburunskaya Cave. The species C. birsteini (blue triangle): Mramornaya Cave. The species C. turbanovi (blue star): Tuakskaya (= Ful-Koba) Cave.

Карта. Распространение всех пяти известных эндемичных троглобионтных видов многоножек-диплопод на Крымском полуострове. Вид Syrioiulus kovali (желтый квадрат): 1 - пещера Мангупская I (= MK-1), 2 - пещера Мамут-Чокрак, 3 - пещера Скельская, 4 - пещера Дружба, 5 - пещера Авантюра. Вид Caucasodesmus svetlanae (зеленый круг): 1 — пещера Скельская, 2 пещера Кузнецова (= Корыта), 3 - пещера Кристальная (= им. Максимовича). Вид С. tauricus (красный ромб): 1 - пещера БерюТешик (= Партизанская), 2 - пещера Виллябурунская. Вид С. birsteini (синий треугольник): пещера Мраморная. Вид C. turbanovi (голубая звезда): пещера Туакская (= Фул-Коба).

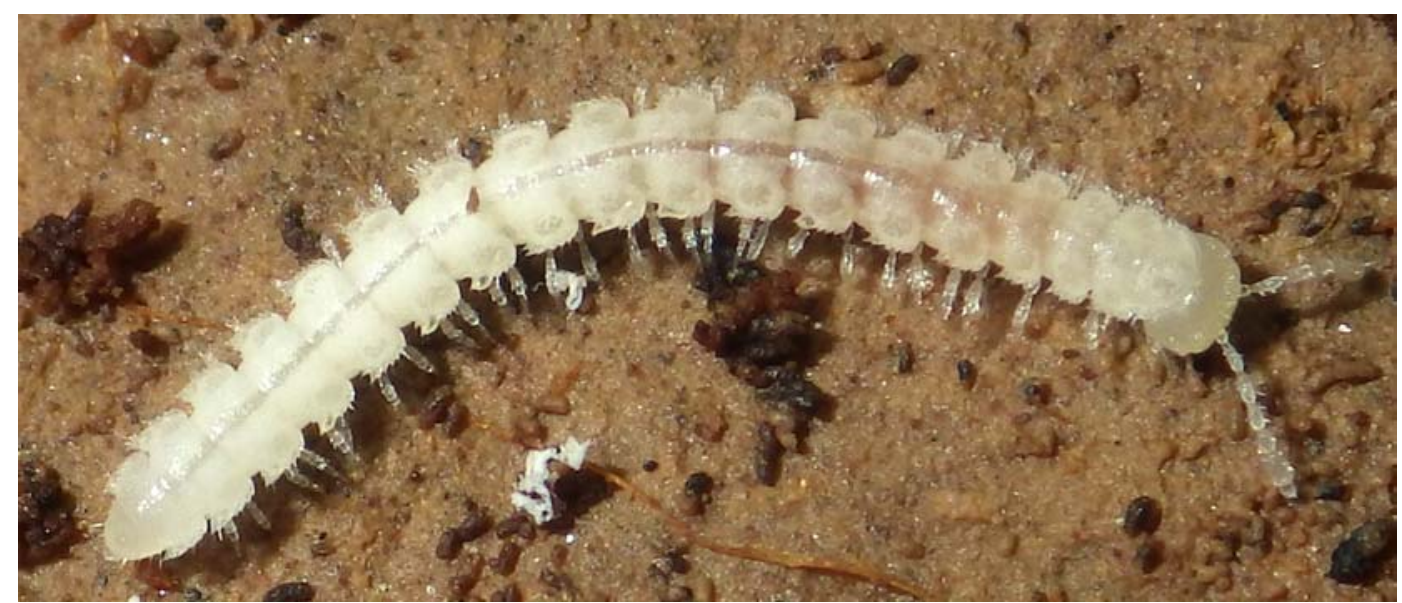

Fig. 3. Live picture of Caucasodesmus birsteini Golovatch, Turbanov et VandenSpiegel, 2017, $\bigcirc^{7}$ from the Mramornaya Cave.

Рис. 3. Прижизненная фотография Caucasodesmus birsteini Golovatch, Turbanov et VandenSpiegel, 2017, О из пещеры Мраморная.

Turbanov et al., 2016] which lies very close to the Villyaburunskaya Cave, the locus typicus [Golovatch, 2011]. All samples of C. tauricus stem from caves (Map) located at the periphery of the Malyi Babulgan area's montane depression at the northwestern edge of the central part of the Ai-Petri Karst Massif (= Ai-Petri Yaila) [Vakhrushev, 2009] which are thin or thick, stratified, Tithonian limestones of Jurassic age [Amelichev, Matyushkin, 2011].
Among all four presently known Crimean species of Caucasodesmus, each is confined to caves in its own karst or part of a karst. Thus, C. turbanovi Golovatch et VandenSpiegel, 2015 occurs solely in the Karabi Karst Massif (= Karabi Yaila), both $C$. svetlanae and C. tauricus, although inhabiting different caves in the same, largest Ai-Petri Karst Massif (= Ai-Petri Yaila), are restricted to its south- and northwestern parts, respectively, whereas $C$. birsteini Golo- 

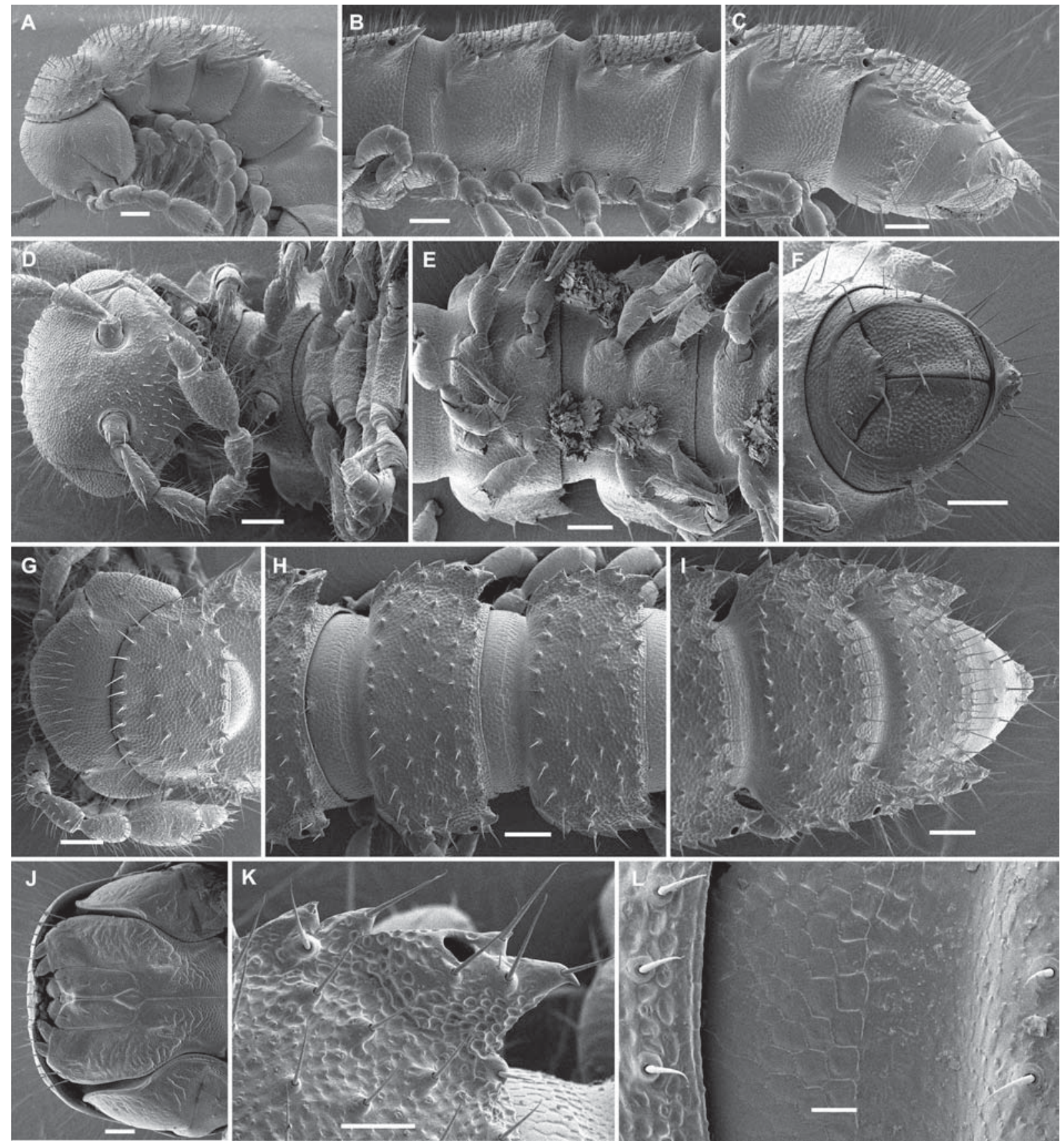

Fig. 4. SEM micrographs to show structural details of Caucasodesmus tauricus Golovatch, 2011, $0^{\text {Th }}$ from the Beryu-Teshik (= Partizanskaya) Cave: A, D, G - anterior part of body, lateral, ventral and dorsal views, respectively; B, E, H - midbody segments, lateral, ventral and dorsal views, respectively; C, F, I - posterior part of body, lateral, ventral and dorsal views, respectively; J - head, ventral view; $\mathrm{K}$ - midbody poriferous paratergum, lateral view; $\mathrm{L}$ - texture of tegument, dorsal view. Scale bars: $0.1 \mathrm{~mm}(\mathrm{~A}-\mathrm{J}), 0.05 \mathrm{~mm}(\mathrm{~K})$, $0.02 \mathrm{~mm}(\mathrm{~L})$.

Рис. 4. SEM-микрографии, показывающие структурные детали строения Caucasodesmus tauricus Golovatch, 2011, О ○ $^{7}$ пещеры Берю-Тешик (= Партизанская): A, D, G - передняя часть тела, соответственно сбоку, снизу и сверху; В, Е, H среднетуловищные сегменты, соответственно сбоку, снизу и сверху; С, F, I - задняя часть тела, соответственно сбоку, снизу и сверху; J - голова, снизу; $\mathrm{K}$ - среднетуловищный несущий пору паратергит, сбоку; L — текстура покровов, сверху. Масштаб: 0,1 мм (A-J), 0,05 мм (K), 0,02 мм (L).

vatch, Turbanov et VandenSpiegel, 2017 (Fig. 3) populates a cave in the Tshatyr-Dagh Karst Massif (= Tshatyr-Dagh Yaila) [cf. Golovatch et al., 2017].

Allopatric speciation in Caucasodesmus (Map) could have occurred from the same Crimean epi- or endogean ancestor during Pleistocene glacial and/or interglacial phases along with the formation and isolation of the karst massifs of Montane Crimea. Such a viewpoint agrees well with the known evidence derived from the geological evolution and age of Crimea's karst [Muratov, Nikolaev, 1940; Muratov, 

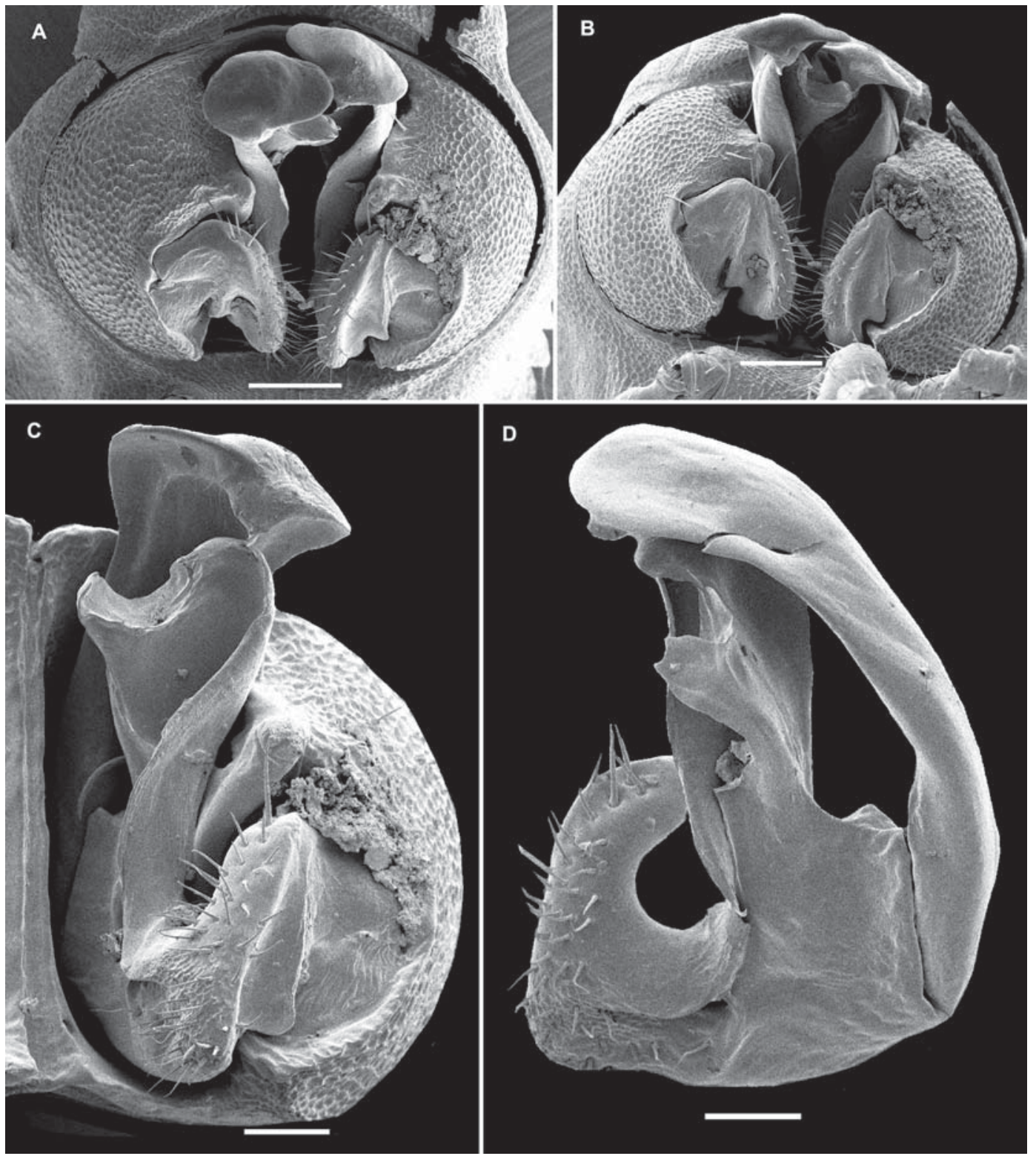

Fig. 5. SEM micrographs to show structural details of the gonopods of Caucasodesmus tauricus Golovatch, 2011, $O^{7}$ from the the Beryu-Teshik (= Partizanskaya) Cave: A, B — both gonopods in situ, ventral and ventrocaudal views, respectively; C, D - left gonopod, ventral and mesal views, respectively. Scale bars: $0.1 \mathrm{~mm}(\mathrm{~A}, \mathrm{~B}), 0.05 \mathrm{~mm}(\mathrm{C}, \mathrm{D})$.

Рис. 5. SEM-микрографии, показывающие структурные детали строения гоноподов Caucasodesmus tauricus Golovatch, 2011, $\mathrm{O}^{7}$ из пещеры Берю-Тешик (= Партизанская): A, В - оба гонопода на месте, соответственно снизу и одновременно снизу и сзади; C, D - левый гонопод, соответственно снизу и изнутри. Масштаб: 0,1 мм (A, B), 0,05 мм (C, D).

1960; Dublyansky, 1977; Vakhrushev, 2001, 2010] and suggests a Pleistocene age of its present-day troglobiont fauna [Prokopov, Turbanov, 2017].

\section{Syrioiulus kovali (Golovatch, 2008), comb.n.} Figs 6, 7.

Amblyiulus kovali Golovatch, 2008: 103 (original description). Amblyiulus kovali - Golovatch, VandenSpiegel, 2015: 1 (mere mention); Turbanov et al., 2016: 1291 (listing, fig. 8); Golovatch et al., 2017: 107, 110 (new records, listing and descriptive notes on morphological variation); Turbanov, 2018a: 264 (notes on ecology and conservation)
MATERIAL. $2 \sigma^{\top} \sigma^{\top}$, Crimea, Bakhchisaray Distr., above Khodzhi-Sala Village, steep escarpment of Baba-Dagh Plateau (= Mangup-Kale Gorodishche), Mangupskaya I (= MK-1) Cave, 28.IV.2017; 1 ऽ, 1 , , same cave, 3.V.2018, all leg. I.S. Turbanov.

REMARKS. This is the most widespread diplopod among Crimea's presumed endemic troglobites (Map). The above new samples represent a new record, show only minor morphological variations (Figs 6,7) and confirm the species identity.

Following a recent redefinition of Amblyiulus Silvestri, 1896 vs. Syrioiulus Verhoeff, 1914 by Golovatch [2018], because kovali lacks a third, rod-shaped branch on the opisthomere so characteristic of Amblyiulus, this species 


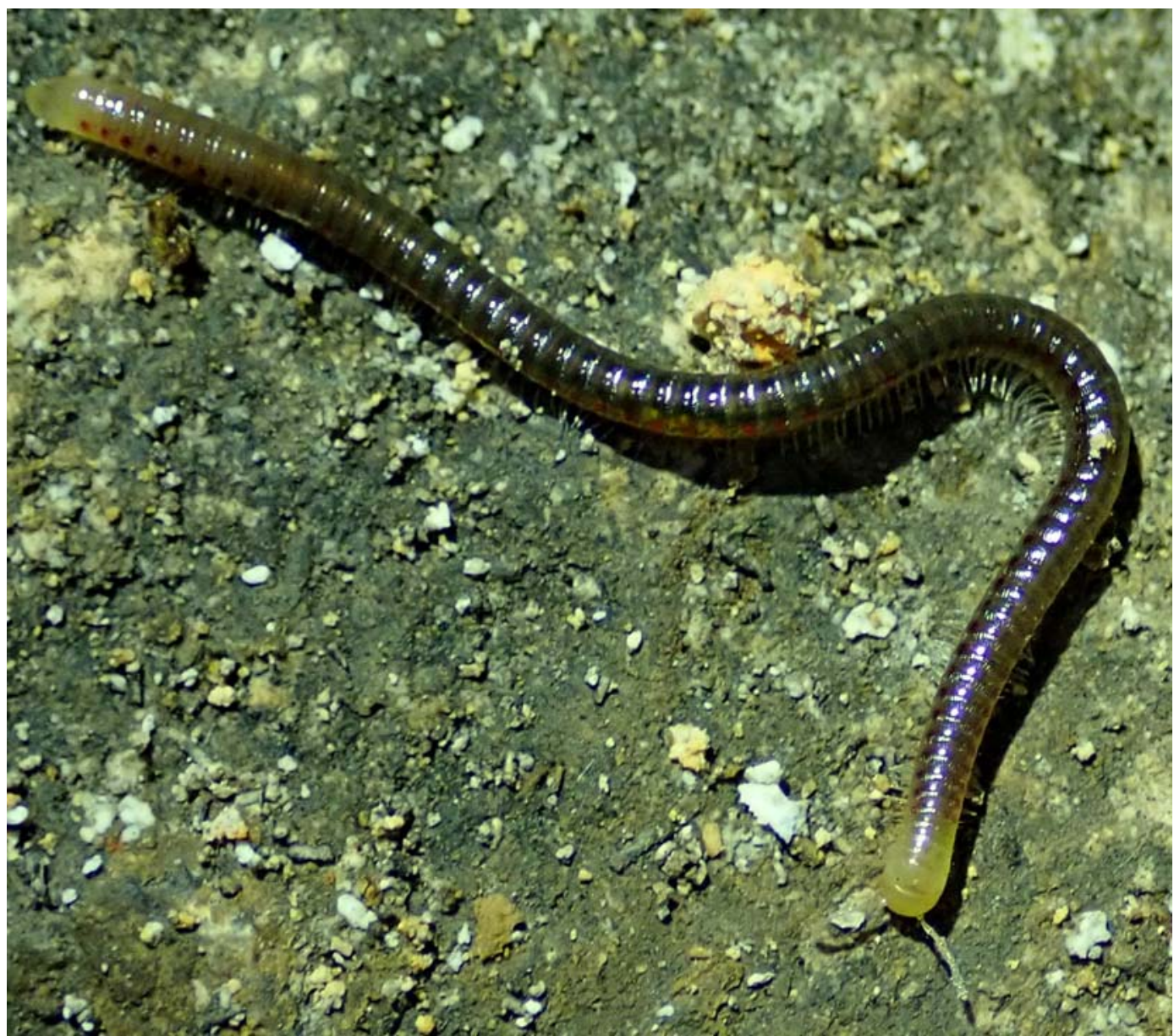

Fig. 6. Live picture of Syrioiulus kovali (Golovatch, 2008), $\sigma^{7}$ from the Mangupskaya I (= MK-1) Cave.

Рис. 6. Прижизненная фотография Syrioiulus kovali (Golovatch, 2008), О’ из пещеры Мангупская I (= MK-1).

must be transferred, like most if not all other ex-Amblyiulus from the Caucasus, Anatolia and Iran, to Syrioiulus. This results in the following new combination: Syrioiulus kovali (Golovatch, 2008), comb.n. ex Amblyiulus Silvestri, 1896.

\section{Discussion}

According to the karst and geomorphological regionalization of the Crimean Peninsula [Vakhrushev, 2009], all known records of S. kovali (Map) are restricted to three closely located karst regions of southwestern Crimea which are distinguished by their lithostratigraphic, hydrological and orographic features. Thus, the caves Skelskaya, Druzhba and Avantyura are situated either in the western or the northeastern part of the Ai-Petri Karst Massif (= Ài-Petri Yaila), whereas the Mamut-Tshokrak Cave is in the Baydarsko-Balaklavsky Karst Massif (= Baydarskaya Yaila). These two massifs belong to the Montane Crimean Karst Region, in contrast to the Mangupskaya I Cave (=MK-1) which lies within the Bakhchisaray Karst Massif of the Foothill Crimean Karst Region [Vakhrushev, 2009], more specifically, in the southeastern part of the Baba-Dagh (= Mangup) Outlier Massif inside Danish bryozoan limestones overlying Maastrichitian, Cretaceous siltstones [Klimchouk et al., 2013].

The above reports of $S$. kovali from the Mangupskaya I Cave, coupled with the still unpublished records of yet unidentified, but apparently troglobitic Campodeidae and Oniscidea from the same cave, provide the first reliable evidence for the presence of troglomophic invertebrates in Foothill Crimea's caves. The distribution of $S$. kovali (Map) which covers two presently disconnected karst regions is definitely rooted in the geological history of Crimea. In the Plio- to early Pleistocene, along with the denudation of the Montane Crimean Karst Region (= Main Ridge) from a Cretaceous to Palaeogene cover [Vakhrushev, 2001; Lysenko, 2002] and the orographic isolation of a Foothill Crimean Karst Region (both Inner and Outer ridges) [Vakhrushev, 2001; Klimchouk et al., 2013] during the middle to late Pleistocene, the ancestor of $S$. kovali could have moved to cavernicoly. Unlike that of the Crimean Caucasodesmus which, due to a series of vicariance events, has since formed several allopatric species, $S$. kovali seems to have remained not too markedly differentiated, although this is still to be verified using not only morphological, but also molecular evi- 

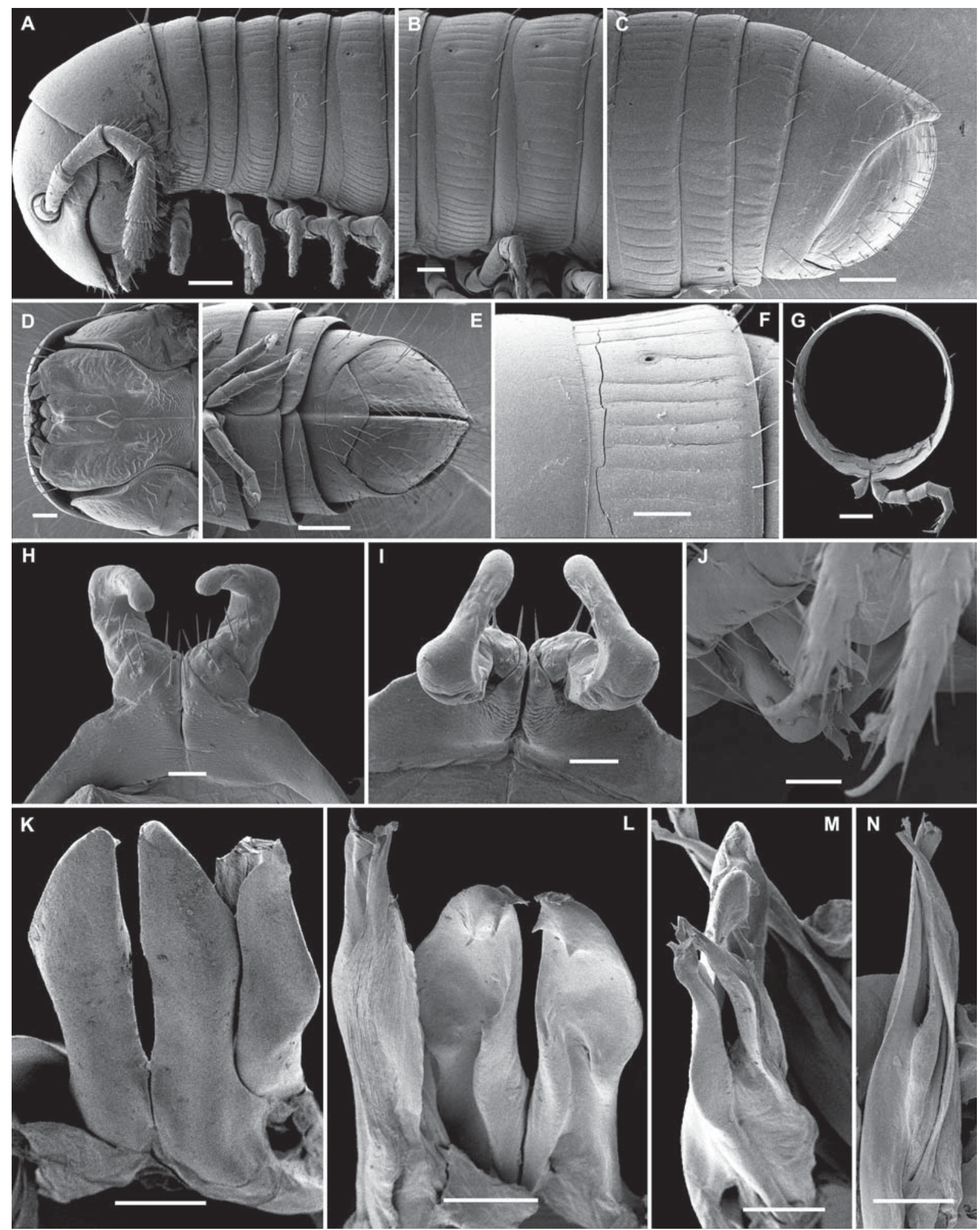

Fig. 7. SEM micrographs to show structural details of Syrioiulus kovali (Golovatch, 2008), $0^{7}$ from the Mangupskaya I $(=$ MK-1) Cave: A, D - anterior part of body, lateral and ventral views, respectively; B - midbody segments, lateral view; C, E - posterior part of body, lateral and ventral views, respectively; F — midbody metazonum, lateral view; G - cross-section of a midbody segment, caudal view; H, I - leg-pair 1, oral and ventral views, respectively; J - gonopods in situ, lateral view; $\mathrm{K}-\mathrm{M}$ - both gonopods, oral, caudal and sublateral views, respectively; $\mathrm{N}$ - posterior gonopod, mesal view. Scale bars: $0.2 \mathrm{~mm}(\mathrm{~A}-\mathrm{C}, \mathrm{E}, \mathrm{G}), 0.1 \mathrm{~mm}(\mathrm{D}, \mathrm{F}, \mathrm{K}-\mathrm{N}), 0.05 \mathrm{~mm}(\mathrm{H}-\mathrm{J})$. 
dence. It is also possible that $S$. kovali is not a specialized troglobite, but rather a geobiont or MSS-dweller which, like the numerous congeners across the Caucasus and elsewhere in the eastern Mediterranean (SG, personal observations) that seem to represent geobites, has successfully penetrated quite a few caves in southwestern Crimea.

Ectoparasitic fungi Troglomyces manfrediae S. Colla (Colla, 1932) (Laboulbeniales, Ascomycota) have been revealed on $S$. kovali collected from the Skelskaya Cave [Santamaría et al., 2018].

ACKNOWLEDGEMENTS. This study by Ilya S. Turbanov was performed in the framework of the state assignment of FASO Russia (topics No. AAAA-A18118012690106-7, AAAA-A18-118012690105), supported in part by RFBR (project No. 17-54-40017 Abh a). Kirill Mikhailov (ZMUM) has kindly helped us incorporate the new samples in the ZMUM collection.

\section{References}

Amelichev G.N., Matyushkin B.E. 2011. [Karst and caves at the northeastern edge of the Baydarsky Depression (Mountainous Crimea)] // Speleology and Karstology. No.6. P.25-35 [in Russian, with Ukrainian and English summaries].

Golovatch S.I. 2008. On three remarkable millipedes (Diplopoda) from the Crimea, Ukraine // International Journal of Myriapodology. Vol.1. P.97-110.

Golovatch S.I. 2011. The millipede genus Caucasodesmus Golovatch, 1985, with the description of a new species from the Crimea, Ukraine (Polydesmida, Diplopoda, Trichopolydesmidae) // Zootaxa. Vol.93. P.1-8. http://dx.doi.org/10.3897/zookeys.93.1159

Golovatch S.I. 2018. The millipede subfamily Pachyiulinae in Israel, with the description of a new species (Diplopoda: Julida: Julidae) // Zoologicheskii zhurnal. T.97. No.7. P.791-805.

Golovatch S.I., VandenSpiegel D. 2015. Two new species of the millipede genus Caucasodesmus Golovatch, 1985 from the Crimea, Russia (Diplopoda, Polydesmida, Trichopolydesmidae) // Russian Entomological Journal. Vol.24. No.1. P. P.1-6.

Golovatch S.I., Turbanov I.S., VandenSpiegel D. 2017. Contributions to the cave millipede fauna of the Crimean Peninsula (Diplopoda), with the description of a new species // Arthropoda Selecta. Vol.26. No.2. P.103-111.

Dublyansky V.N. 1977. [Karst caves and mines of Montane Crimea]. Leningrad: Nauka. 183 pp. [In Russian]

Klimchouk A.B., Timokhina E.I., Amelichev G.N., Dublyansky Y.V., Shpetl K. 2013. [Hypogean karst of Foothill Crimea and its geomorphological role]. Simferopol: DIAIPI. 204 pp. [In Russian]
Lysenko N.I. 1964. [To the stratigraphy of the Tithonian-Valangian deposits at the southern edge the Baydarskaya Depresssion in Crimea] // Doklady AN SSSR. T.159. No.4. P.122-130 [in Russian].

Lysenko N.I. 2002. [On a new record of Lower Cretaceous deposits in a Crimean yaila] // Priroda. No.1. P.2-4 [in Russian].

Muratov M.V., Nikolaev N.I. 1940. [A Quaternary history and relief evolution of Montane Crimea] // Uchenye zapiski Moskovskogo gosudarstvennogo universiteta. Ò.48. P.65-73 [in Russian]

Muratov M.V. 1960. [A brief sketch of the geological structure of the Crimean Peninsula]. Moscow: State Scientific and Technical Publishing House of Literature on the Geology and Conservation of Mineral Resources. 208 pp. [In Russian]

Prokopov G.A., Turbanov I.S. 2017. [To the question of speleofauna formation in the Crimean Peninsula] // Materials of the II All-Russia Youth Conference "Biospeleological studies in Russia and adjacent countriues [Materialy II Vserossiyskoy molodezhnoy koferentsii "Biospeleologicheskie issledovaniya $\mathrm{v}$ Rossii i sopredel'nykh gosudarstvakh"]. Moscow: 1-2 December 2016. Yaroslavl: Filigran'. P.99-106 [in Russian].

Santamaría S., Enghoff H., Reboleira A.S.P.S. 2018. New species of Troglomyces and Diplopodomyces (Laboulbeniales, Ascomycota) from millipedes (Diplopoda) // European Journal of Taxonomy. Vol.429. P.1-20. https://doi.org/10.5852/ejt. 2018.429

Turbanov I.S. 2015. [Caucasodesmus tauricus Golovatch, 2011] // Ivanov S.P., Fateryga A.V. (eds.). Red Data Book of the Republic of Crimea: Animals. Simferopol: IT "Arial". P.69 [in Russian].

Turbanov I.S. 2018a. [Amblyiulus kovali Golovatch, 2008] // Samoylov S.Y. et al. (eds.). Red Data Book of the City of Sevastopol. Kaliningrad-Sevastopol: ID "ROST-DOAFK". P.264 [in Russian].

Turbanov I.S. 2018b. [Caucasodesmus svetlanae Golovatch et VandenSpiegel, 2015] // Samoylov S.Y. et al. (eds.). Red Data Book of the City of Sevastopol. Kaliningrad-Sevastopol: ID "ROST-DOAFK". P.265 [in Russian].

Turbanov I.S., Palatov D.M., Golovatch S.I. 2016. [The state of the art of biospeleology in Russia and other countries of the former Soviet Union: A review of cave (endogean) invertebrate fauna. 2. Arachnida - Acknowledgements] // Zoologicheskii zhurnal. Vol.95. No.11. P.1283-1304 [in Russian; English translation: Entomological Review, 2016, 96, 9: 1297-1333].

Vakhrushev B.A. 2001. [Palaeogeography of Crimea in the light of the newest karstological and speleological studies] // Culture of the peoples of Cispontia [Kul'tura narodov Prichernomorya]. No.17. P.11-18 [in Russian].

Vakhrushev B.A. 2009. [Regionalization of karst of the Crimean Peninsula] // Speleology and Karstology. No.3. P.39-46 [in Russian, with Ukrainian and English summaries].

Vakhrushev B.A. 2010. [Crimean mountains] // Stetsyuk V.V. (ed.). Relief of Ukraine: Initial manual [Rel'ef Ukrainy: navnachalnyi posibnik]. Kiev: Slovo. P.432-485 [in Ukrainian].

Responsible editor K.G. Mikhailov

Рис. 7. SEM-микрографии, показывающие структурные детали строения Syrioiulus kovali (Golovatch, 2008), О из пещеры Мангупская I (= MK-1): A, D — передняя часть тела, соответственно сбоку и снизу; В — среднетуловищные сегменты, сбоку; С, Е задняя часть тела, соответственно сбоку и снизу; F - среднетуловищный метазонит, сбоку; $\mathrm{G}$ - поперечный разрез через среднетуловищный сегмент, сзади; Н, I - пара ног 1 , соответственно спереди и снизу; J — гоноподы, сбоку; K-M - оба гонопода, соответственно спереди, сзади и почим сбоку; $\mathrm{N}$ - задний гонопод, изнутри. Масштаб: 0,2 мм (A-C, E, G), 0,1 мм (D, F, $\mathrm{K}-\mathrm{N}), 0,05$ мм (H-J). 